\title{
DIE OPLEIDING VAN BEDRYFSIELKUNDIGES AAN DIE UNIVERSITEIT VAN STELLENBOSCH
}

\section{J.C.D. AUGUSTYN, W.S. DE VILLIERS, I.VAN W. RAUBENHEIMER EN I.J. VAN BILJON}

\author{
DEPARTEMENT BEDRYFSIELKUNDE \\ UNIVERSITEIT VAN STELLENBOSCH
}

Die aanbieding van Bedryfsielkunde aan die Universiteit van Stellenbosch gaan sover terug as 1943 toe daar binne die Departement Sielkunde met 'n afsonderlike kursus in Bedryfsielkunde vir B.Comm.-studente 'n begin gemaak is. Hierdie kursus is in 1949 uitgebrei tot die derde jaar, toe dit moontlik geword het om 'n B.Comm.-graad met Bedryfsielkunde as een van die hoofvakke te behaal.

Vandag is die Departement Bedryfsielkunde 'n volwaardige departement binne die Fakulteit van Handel en Administrasie. Waar een lektor oorspronklik verantwoordelik was vir die doseer van hierdie kursus, het die Departement tans 'n personeel van 13, bestaande uit onder andere twee professore, een senior lektor, ses lektore, 'n meganikus, 'n tegniese assistent en tiksters/sekretaresses.

Die aantal ingeskrewe studente in Bedryfsielkunde het gedurende die tydperk 19491978 meer as tienvoudig toegeneem soos die volgende tabel onder andere aandui:

\section{$\underline{\text { TABEL } 1}$}

AANTAL STUDENTE IN DIE BEDRYFSIELKUNDE AAN DIE UNIVERSITEIT STELLENBOSCH VAN 1949-1978

\begin{tabular}{|l|c|c|c|c|c|c|c|c|c|c|c|}
\hline \multicolumn{1}{|c|}{ JAAR } & 1949 & 1964 & 1966 & 1968 & 1970 & 1972 & 1974 & 1975 & 1976 & 1977 & 1978 \\
\hline Voorgraads & 74 & 450 & 598 & 781 & 891 & 898 & 850 & 635 & 759 & 730 & 742 \\
Nagraads & 0 & 5 & 7 & 11 & 20 & 20 & 35 & 30 & 33 & 33 & 45 \\
\hline
\end{tabular}

'n Interessante kenmerk is die skerp styging in die aantal nagraadse studente. Hierdie groei in studentegetalle kan moontlik ook gesien word as 'n indirekte aanduiding van die dinamiese groei van die Bedryfsielkunde in Suid-Afrika. Verskeie studente skryf in vir die honneursgraad of vir 'n magistergraad in die Bedryfsielkunde en studeer dan verder terwyl hul reeds in 'n praktiese werksituasie staan. 
Die Departement beset tans 'n twee-verdieping gebou wat beskik oor uitstekende fasiliteite soos voorlesinglokale, praktiese lokale, gevallestudie-kamers, 'n biblioteek vir studente, projektorkamers en toetslokale. Alle opleiding word reeds etlike jare gedupliseer by die Buitemuurse Afdeling van die Fakulteit van Handel en Administrasie in Bellville. Die Departement Bedryfsielkunde handhaaf noue kontak met verskillende sake-ondernemings in Wes-Kaapland en verskillende navorsingsprojekte word deur nagraadse studente op aandrang van hierdie ondernemings aangepak. Periodiek tree die Departement ook in konsulterende hoedanigheid op ten opsigte van probleme wat ondernemings mag ondervind. Hierdeur word daar nie net diens verskaf aan ondernemings nie, maar word die Departement ook op hoogte gehou van die behoeftes en probleme van die praktyk en kan kursusse sodanig ingerig word om hierin te voorsien.

\section{INHOUD VAN KURSUSSE - 'N BRË̈, WETENSKAPLIKE ORIËNTASIE}

Bedryfsielkunde kan aan die Universiteit van Stellenbosch voorgraads as hoof- of byvak vir die grade B.Comm., B.Econ. en B.Admin. gevolg word. Spesiale kursusse word ook aangebied vir studente in Ingenieurswese, Bosbou, Landbou, Huishoudkunde, Rekenaarswetenskap, Dieetkunde, Kuns en Arbeidsterapie. Nagraadse studie in die Bedryfsielkunde kan tot op doktorale vlak gevoer word na verwerwing van 'n honneurs- en meestersgraad in dié rigting.

Die doelstelling met opleiding in die Bedryfsielkunde is om aan studente die nodige breë akademiese agtergrond en oriëntasie te voorsien wat as 'n noodsaaklike voorvereiste vir sukses in mannekraghantering gesien word. Benewens hierdie oriëntering is die kursusse ook prakties gerig om sodoende by die student die nodige vaardighede te ontwikkel.

In die eerste semester van die eerstejaar word die mens as individu bestudeer en die kursus sluit die volgende in: Algemene agtergrond van die funksionering van die menslike liggaam, sintuie en brein, waarneming, aandag, leerprosesse en aspekte van intelligensie. Hierdie basiese funksioneringsbeginsels word egter ook telkens deurgetrek na die bedryfs- en beroepslewe. Vanaf die tweede semester val die klem op die doeltreffende benutting van die individu in die werksituasie en word basiese begrippe soos die personeeldepartement, organisasiestruktuur, taksonomie van vermoëns, produktiwiteit, werksomgewing, metodestudie, bewegingstudie, werksmeting en verbruikersgedrag bestudeer. 
In die tweede en derde jare maak die student nie slegs kennis met die denke en filosofie van die Bedryfsielkunde nie, maar ook met spesifieke programme, praktyke en prosedures wat doeltreffende mannekragbenutting in die hand werk.

Onderwerpe wat deel uitmaak van die kursus in die tweedejaar is onder andere loopbaanbeplanning en ontwikkeling, beroepsklassifikasie, geestesgesondheid, beroepsaanpassing, rekrutering, keuring, plasing en induksie van werkers, posontleding, opleiding, poswaardering, arbeidsverhoudinge en gesamentlike bedinging, groepsgedrag, beginsels van motivering, lyn- en stafverhoudinge, algemene beginsels van sielkundige meting en toetsing (A-Vlak).

In die derdejaar bestudeer die student werk van 'n meer gevorderde aard. So word spesifieke aandag aan onder andere die volgende gewy: Die funksie en posisie van die personeeldepartement in die moderne onderneming, personeelbeleid, wetenskaplike mannekragbeplanning, mannekragprobleme in Suid-Afrika, prestasie en produktiwiteitsbeoordeling, bestuurs- en organisasieontwikkeling, basiese loon- en salarisadministrasie, aansporingsvergoeding, byvoordele, nywerheidswetgewing, vakbondbeleid, arbeidsomset, werksafwesigheid, veiligheid en gesondheid, die personeelinligtingsisteem, kapitale investering in mensemateriaal, skiktyd en die rol van personeelbestuur in die arbeidsituasie in Suid-Afrika. Om die student 'n gebalanseerde oriëntasie tot die wetenskaplike bestuur van mannekrag te gee, maak hy ook kennis met die sisteembenadering tot organisatoriese gedrag, met leierskap, organisasieteorie, deelnemende bestuurstegnieke, weerstand teen verandering, 'n kritiese ontleding van menslike verhoudinge en onderhoudvoering gebaseer op wetenskaplike beginsels. Verder word ook aandag verleen aan die Verbruikersielkunde en die Ergonomika.

Omdat die bestuur van mannekrag besondere metingsvaardigheid asook 'n vermoë om syferdata te hanteer, vereis, word die student ook aan die volgende velde van die psigometrie blootgestel: Statistiese beskrywings- en ontledingsmetodes, metingstegniek, metingsprosedure, metingsteorie en navorsingsmetodiek.

Honneursstudente in die Bedryfsielkunde volg 'n aantal hoofrigtings wat bestaan uit sekere kombinasies van die volgende vakke: Differensiële sielkunde, beroepsielkunde, waarneming, organisasiesielkunde, leerteorie, persoonlikheidsleer, personeel- en bestuursielkunde, sosialegedrag, ergonomika, denkrigtings in die bedryfsielkunde, verbruikersgedrag, psigometrika, bedryfsgeestesgesondheid. 
Die magistergraad kan op twee wyses verwerf word:

(a) Die student lewer 'n verhandeling in wat die resultaat is van oorspronklike navorsing of (b) die student neem die kursusse wat nie gedurende die honneursjaar deurloop is nie en dien daarbenewens 'n skripsie van beperkte omvang in.

Vir die doktorsgraad word 'n proefskrif vereis, wat die resultate van uitgebreide selfstandige studie en navorsing is.

\section{DIE WYSE WAAROP OPLEIDING GESKIED - LESINGS ALLEEN NIE VOLDOENDE}

Etlike jare gelede is daar besef dat vanuit 'n opvoedkundige oogpunt beskou en vanweë die getalsterkte van ons studente die voorlesing alleen nie 'n doeltreffende opleidingsmetode is nie. Daar is gevolglik begin met 'n kleingroepstelsel waarvolgens die hele klas ingedeel word in klein groepies van 8 tot 10 elk. Hierdie groepe doen dan weekliks gevallestudiebesprekings, rolspelsessies of kry oefening in die hanteer van psigometriese probleme. Op hierdie wyse word waardevolle ervarings opgedoen in die toepassing van 'n groot verskeidenheid akademiese beginsels in die oplossing van praktiese personeelprobleme. Doeltreffende fasiliteite word gebruik vir hierdie kleingroepoefeninge - byvoorbeeld waarnemingslokale wat voorsien is van eenrigtingglaspanele, mikrofone, luidsprekers, gewone bandopnemers en geslotebaantelevisie.

Studente sien egter nie slegs die praktiese demonstrasie van teoretiese beginsels gedurende die voorgraadse studiejare nie, maar kry ook spesifieke oefening in tegnieke soos byvoorbeeld posontleding, metodestudie en werksmeting.

Op honneursvlak leen hierdie benadering hom uitstekend tot sensitiwiteitsopleiding en ander gevorderde opleidingstegnieke. Op hierdie vlak word dus selde gebruik gemaak van formele voorlesings. Studente kry opdragte volgens 'n voorafopgestelde program, waar elke student die geleentheid kry om sy betrokke opdrag of taak voor te dra. Hierna volg 'n groepbespreking oor die betrokke onderwerp. Voorbeelde van sulke opdragte is byvoorbeeld "Doelwitbestuur binne die Personeeldepartement", "Die Doeltreffende benutting van Nieblanke arbeid in die Suid-Afrikaanse Industrie" en "Die Rol van Finansiële Vergoeding in Organisatoriese Doeltreffendheid". 
Die Departement Bedryfsielkunde is deeglik daarvan bewus dat skakeling met die praktyk noodsaaklik is vir die doelmatige opleiding van studente. Voordat 'n student toegelaat word tot die derdejaarskursus, word hy verplig om vir 'n periode van ten minste vier weke praktiese ondervinding in personeelwerk binne 'n goedgekeurde bedryfsorganisasie op te doen. Hy moet voorts 'n verslag inlewer oor hierdie praktiese werk wat hy verrig het. In die derdejaar moet elke student ' $n$ selfstudieprojek voltooi oor 'n gekose onderwerp in die personeelveld. Die punte wat hiervoor behaal word word in ag geneerm by die berekening van die betrokke student se finale klassyfer.

Die personeel van die Departement het ook skakeling met 'n hele aantal ondernemings. Konsultasiewerk word byvoorbeeld periodiek onderneem, en informele samesprekings word gehou. Om aan voor- sowel as nagraadse studente 'n insig in die praktiese sy van personeelwerk te gee, word prominente personeelamptenare vanuit die praktyk periodiek gevra om op te tree as gassprekers.

\section{TEENSWOORDIGE EN MOONTLIKE TOEKOMSTIGE ONTWIKKELING - 'N STEEDS OMVANGRYKER DIENS}

Die Bedryfsielkunde is in wese 'n toegepaste wetenskap en is daarom primêr op die praktyk gerig vir sy probleemstellinge. In sy opleiding laat die Departement hom lei deur die behoeftes van die praktyk en word daar dus gepoog om skakeling met die praktyk te kry vir die uitbreiding en toepassing van wetenskaplike kennis ten einde mensemateriaal so produktief as moontlik te benut.

Vanuit hierdie basiese oriëntasie en ten einde steeds 'n beter diens aan die student en die praktyk te lewer, is die volgende projekte onlangs van stapel gestuur:

- $\quad$ Die uitbreiding van skakeling met die praktyk deur middel van samesprekings met vooraanstaande personeelamptenare, prominente gassprekers en deur middel van konsulteerwerk waar lede van die Departement ' $n$ projekspan vorm met lede van die betrokke organisasie om sodoende 'n besondere diens aan die organisasie te kan lewer. 
- Die aanmoediging van alle nagraadse studente, en waar moontlik ook voorgraadse studente, om aktiewe lede van SIRSA en die IPB te word.

- Die daarstelling aan die begin van 1975 van 'n onafhanklike, tweetalige tydskrif, naamlik "Perspektiewe in die Bedryfsielkunde/Perspectives in Industrial Psychology" waarin onder andere oor personeelvraagstukke van aktuele belang asook relevante navorsingsresultate publiseer word.

- Dit word verder in die vooruitsig gestel dat 'n instituut in die Departement gestig word wat gemoeid sal wees met diensfunksies soos beroepsleiding, personeelnavorsing en personeelkonsultasie.

- Die aanbieding van 'n reeks Lente-Herfsseminare in Bedryfsielkunde aan lede van organisasies in beide die Openbare en Privaatsektore. Die gewildheid van die seminare neem steeds toe en 'n aansienlike uitbreiding daarvan word in die vooruitsig gestel.

Omdat dit dan die strewe van die Departement Bedryfsielkunde is om diepte en perspektief by die student te ontwikkel ten einde hom in staat te stel om meer as net 'n oppervlakkige tegniese kennis van menslike gedrag in die praktyk te ontwikkel, behoort die gegradueerde in Bedryfsielkunde 'n gesogte personeelkwekeling te wees, aangesien hy ' $n$ praktiese dog teoretiese goed gefundeerde kursus gevolg het wat toegespits was op die werksituasie wat hy gaan betree. 